\title{
Effects of Dietary Fats on Triacylglycerol Composition and Structure of Egg Yolk Lipids
}

\author{
Akihiro Hirata*, Tetsuya Masuda*, Teiji Kimura* and Yoshiyuki Ohtake* \\ * College of Agriculture \& Veterinary Medicine, Nihon University, 3-34-1, \\ Shimouma, Setagaya-ku, Tokyo, 154
}

\begin{abstract}
Effects of dietary soybean oil, coconut oil, lard and beef tallow on the changes in triacylglycerol (TG) composition and structure in egg yolk lipids of laying hens were studied. Generally, the fatty acid composition of egg yolk TG reflected partially that of the dietary fats fed to hens, though, the short chain saturated fatty acids $\left(\mathrm{C}_{8: 0}, \mathrm{C}_{10: 0}\right)$ were not availably utilized for the egg yolk lipid formation. Egg yolk TG from hens fed soybean oil, lard and beef tallow was commonly composed of $\mathrm{C}_{50}, \mathrm{C}_{52}$ and $\mathrm{C}_{54}$ species as main TG components. More TG species of $\mathrm{C}_{44} \sim \mathrm{C}_{50}$ were contained in egg yolk of coconut oil group than in that of the other diet groups, while, $\mathrm{C}_{52}$ and $\mathrm{C}_{54}$ components were less in coconut oil group. Egg yolk lipid of soybean oil group contained less amounts of TG comprising monoenoic acids and more of TG comprising dienoic acid than the other groups. Lipid of coconut oil group contained the most amount of $\mathrm{S}_{2} \mathrm{M}$ and the least of $\mathrm{U}_{3}$ among the experimented diet groups. Lipids from lard and tallow group comparatively resembled each other in distribution pattern of TG species. In egg yolk TG from every dietary group, saturated fatty acids were preferentially esterified at position 1 of TG, on the contrary, position 2 comprised predominantly unsaturated fatty acids. Position 3 was largely occupied by $\mathrm{C}_{18: 1}$ accompanied with $\mathrm{C}_{16: 1}$. This species specificity of positional distribution of fatty acids in hen's egg TG was not changed regardless of variation of dietary fats fed to hens.
\end{abstract}

Considerable attention has been given to the influence of dietary fats on the composition of hen's egg yolk lipid ${ }^{1)(3)}$. The quantity of lipids in egg yolk cannot be influenced by the type or quantity of fat in the diet of the hen ${ }^{4}$. Whereas, the fatty acid content of egg yolk lipid can be influenced significantly by the fatty acid composition of the $\operatorname{diet}^{5) \sim 8}$. The fatty acid composition of egg yolk is generally a reflection of the dietary fatty acid pattern, and the effects of dietary fats on the egg yolk lipid appeared more distinctly in the fatty acid composition of neutral lipid fraction than in that of polar lipid fraction of egg lipid ${ }^{9}$. As hen's egg yolk neutral lipid is mostly composed of triacylglycerols (TG), the changes of fatty acid composition of yolk lipid affected by dietary fats, may be caused by the variation of composition and structure of TG species found in yolk lipid. A few informations related to the comparative influences of various dietry fats on the properties of egg yolk TG are now available ${ }^{10) 11}$. They have reported the fatty acid composition and distribution at position 2 in the egg yolk TG, and have calculated the TG-type distribution on the basis of 1,3 random-2-random theory. More detailed studies were required to estimate the effects of dietary fats on the changes of characteristics of egg yolk lipids. This investigation was designed to elucidate thoroughly the comparative effects of dietary fats on the composition and molecular species of TG in egg yolk lipids from hens fed fat-supplemented diets.

\section{Materials and Methods}

Treatment of the birds and egg samples Twenty commercial strain of White Leghorn 
hens were divided at random into four groups of five birds in each in individual cages. Hens were maintained on the semi-purified diets supplemented with $10 \%$ of soybean oil, coconut oil, lard or beef tallow for a period of 50 days as described previously ${ }^{9}$. Feed and water were supplied to the birds ad libitum during the experimental period.

Egg samples were collected from hens on the 45 th day of dietary treatment and used for lipid analysis.

Preparation of triacylglycerols

Total lipid of egg yolk was extracted from samples according to the method of FoLCH et al. ${ }^{12)}$ and was separated into neutral lipid and polar lipid fractions by the procedure of MoERCK and BALL ${ }^{13)}$. Then, the yolk triacylglycerol (TG) was isolated from the neutral lipid fraction by Unicil (Clarkson Chem. Co.) silicic acid column chromatography essentially as described by MOERCK and BALL ${ }^{13}$.

Argentation thin-layer chromatography

TG was fractionated according to the degree of unsaturation of component fatty acids by argentation thin-layer chromatography $\left(\mathrm{AgNO}_{3}-\mathrm{TLC}\right) . \mathrm{AgNO}_{3}$ implegnated Silica Gel $G$ plates were prepared by the method of WoOD and SNYDER ${ }^{14}$, and the separation of TG on the plates with a solvent system of hexaneethyl ether-benzene-methanol $(70: 10: 20: 1$, by vol.) was performed by the procedure of Christie and MoOre ${ }^{15)}$. Amount of TG fraction was calculated by reference to the methyl heptadecanoate added as the internal standard, and the TG types present in the fraction were estimated from the results of fatty acid composition determined on the each fraction, as described previously ${ }^{16)}$.

Stereospecific analysis

Stereospecific analysis of TG was carried out essentially following the scheme proposed by BROCKERHOFF ${ }^{17)}$ and modified by CHRISTIE and MoORE $^{18)}$. Briefly, 1, 2 (2, 3)-diacylglycerols (DG) were prepared from TG by reaction with ethyl magnesium bromide and they were converted synthetically into phenyl phospholipids which were hydrolyzed with phospholipase $A_{2}$ of snake venom (Trimersurus fravoridis, Wako
Pure Chemical Industries, Ltd.). The resulting lysophosphatide contained only the fatty acids of position 1 of the original TG, and the fatty acids of position 2 were obtained by pancreatic lipase hydrolysis of the TG. The fatty acid of position 3 could be determined by difference from the composition of the original TG.

Gas-liquid chromatography

Gas-liquid chromatography (GLC) of TG was performed on a Hitachi Model 163 Gas Chromatograph with an on-column injector equipped with dual columns and dual hydrogen flame ionization detectors. The stainless steel columns $(3 \mathrm{~mm} \times 0.5 \mathrm{~m})$ were filled with $2 \%$ Silicon SE-30 packing on $80-100$ mesh Chromosorb WAW. Nitorogen carrier gas flow was set at $60 \mathrm{ml} / \mathrm{min}$., and air and hydrogen gas flow were adjusted to give maximum detector response. The temperature of the injection and detectors was held at $330^{\circ} \mathrm{C}$. The oven temperature was lineary programmed at the rate of $7.5^{\circ} \mathrm{C} / \mathrm{min}$. over the range of $200 \sim$ $300^{\circ} \mathrm{C}$. The peak areas on recorder were computed by YHP 3390 A integrator.

Distributions of various TG types by carbon number in dietary fats and egg yolk TG were estimated by the method described by Kuksis et $a l .{ }^{19)}$. TG type is indicated by the total number of fatty acid carbon. The fatty acid compositions of lipid samples were determined by the procedure described previously ${ }^{20)}$, using Shimadzu GC-6 APF Gas Chromatograph and Shimadzu Chramatopac C-R 2 A.

\section{Results and Discussion}

Effects of dietary fats on the fatty acid composition of egg yolk lipid

Fatty acid compositions of TG in dietary fats and egg yolk lipids were presented in Table 1.

As shown in Table 1, egg yolk lipid from hens fed soybean oil-supplemented diet (soybean oil group) had the highest level of linoleic acid $\left(\mathrm{C}_{18: 2}\right)$ among the all dietary treatment groups.

Egg yolk TG from hens fed coconut oilsupplemented diet (coconut oil group) and soybean oil group had less oleic acid $\left(\mathrm{C}_{18: 2}\right)$ than those of lard and beef tallow feeding groups 
Table 1 Fatty acid composition of triacylglycerol of dietary fats and egg yolk from hens fed fat-supplemented diets

(mole $\mathscr{6})$

\begin{tabular}{|c|c|c|c|c|c|c|c|c|}
\hline \multirow{3}{*}{ Fatty acid* } & \multirow{2}{*}{\multicolumn{4}{|c|}{ Dietary fat }} & \multicolumn{4}{|c|}{ Egg yolk TG } \\
\hline & & & & & & tary & reatm & \\
\hline & $\mathrm{SO}^{* *}$ & $\mathrm{CO}^{* *}$ & $\mathrm{~L}^{* *}$ & $\mathrm{~B}^{* *}$ & SO & $\mathrm{CO}$ & $\mathrm{L}$ & $\mathrm{B}$ \\
\hline $8: 0$ & & 10.3 & & & & & & \\
\hline $10: 0$ & & 7.4 & & & & & & \\
\hline $12: 0$ & & 49.1 & & & 0.3 & 2.2 & $\operatorname{tr}$ & 0.4 \\
\hline $14: 0$ & $\operatorname{tr} * * *$ & 17.4 & 1.8 & 3.7 & 1.8 & 10.0 & 0.7 & 1.2 \\
\hline $14: 1$ & & & 0.2 & 1.0 & 0.2 & 3.5 & $\mathrm{tr}$ & 0.2 \\
\hline $15: 0$ & & & 0.1 & 0.4 & & & & 0.1 \\
\hline $16: 0$ & 11.5 & 7.7 & 25.9 & 25.7 & 22.1 & 27.9 & 25.2 & 27.1 \\
\hline $16: 1$ & & & 3.6 & 3.1 & 2.6 & 7.7 & 4.7 & 4.9 \\
\hline $17: 0 \mathrm{Br}$ & & & & 0.9 & & & & 0.5 \\
\hline $17: 0$ & 0.1 & & 0.4 & 1.2 & 0.2 & 0.1 & 0.2 & 0.5 \\
\hline $17: 1$ & 3.7 & & 0.3 & 0.6 & 0.2 & & 0.3 & 0.6 \\
\hline $18: 0$ & 22.2 & 22.1 & 12.1 & 18.0 & 3.7 & 3.7 & 3.8 & 4.2 \\
\hline $18: 1$ & 53.6 & 4.9 & 43.4 & 40.7 & 37.4 & 37.8 & 55.3 & 54.1 \\
\hline $18: 2$ & 8.6 & 1.1 & 10.5 & 3.6 & 28.8 & 6.4 & 9.0 & 5.6 \\
\hline $18: 3$ & 0.3 & & 0.7 & 0.5 & 2.1 & 0.4 & 0.1 & 0.2 \\
\hline $20: 1$ & & & 1.0 & 0.6 & 0.2 & 0.3 & 0.3 & 0.3 \\
\hline $20: 2$ & & & & & 0.2 & $\operatorname{tr}$ & 0.1 & $\operatorname{tr}$ \\
\hline $20: 3$ & & & & & $\operatorname{tr}$ & $\operatorname{tr}$ & & \\
\hline $20: 4$ & & & & & 0.3 & 0.1 & 0.3 & $\operatorname{tr}$ \\
\hline
\end{tabular}

* Number of carbon atoms : number of double bonds, $\mathrm{Br}$ : branched chain acid

** SO : soybean oil, CO : coconut oil, L : lard and $\mathrm{T}:$ beef tallow

*** tr: trace (below $0.1 \%$ )

(lard group and tallow group). TG of coconut oil group contained considerably more myristic $\left(\mathrm{C}_{14: 0}\right)$, myristoleic $\left(\mathrm{C}_{14: 1}\right)$ and palmitoleic $\left(\mathrm{C}_{16: 1}\right)$ acids compared to that of the other groups. The presence of $\mathrm{C}_{14: 1}$ and $\mathrm{C}_{16: 1}$ in the TG of coconut group was probably due to desaturation of $\mathrm{C}_{14: 0}$ and palmitic acid $\left(\mathrm{C}_{16: 0}\right)$ in the liver of birds, since neither fatty acid was present in the diet. Only a small amount of lautic acid $\left(\mathrm{C}_{12: 0}\right)$ was found in egg TG of coconut group, although the coconut oil contained $50 \%$ of this acid. The low level of $\mathrm{C}_{12: 0}$ in egg TG suggested that only limited amounts of this acid were utilized for egg yolk formation. Fatty acid pattern of TG of lard group was similar to TG of tallow group, except that the former had a little more amounts of $\mathrm{C}_{18: 2}$ and less of $\mathrm{C}_{16: 0}$ than the latter.

In general, the fatty acid composition of hen's egg yolk TG reflected partially that of the dietary fats, though, the short chain saturated fatty acids $\left(\mathrm{C}_{8: 0}\right.$ to $\left.\mathrm{C}_{12: 0}\right)$ found in coconut oil were not availably utilized for the egg yolk lipid formation. Results of present study on coconut oil feeding to hens agreed with the changes in fatty acid compositions of egg lipid observed by MACHLIN et $a l^{7)}$. and CHEN et al. ${ }^{2)}$, and results on soybean oil feeding resembled to that reported by SELL et al. ${ }^{8)}$ and Sim et al. ${ }^{3)}$.

Effects of dietary fats on the egg yolk TG species

The GLC elution patterns for TG of dietary fats and of egg yolk from hens fed experimental diets were shown in Fig. 1 and 2, respectively. The chromatograms for egg yolk TG from soybean, lard and tallow groups showed commonly the presence of major TG species of $\mathrm{C}_{50}, \mathrm{C}_{52}$ and $\mathrm{C}_{54}$ and minor TG of $\mathrm{C}_{42} \sim \mathrm{C}_{48}$. On the contrary, the GLC elution pattern for coconut group recorded the considerably large 

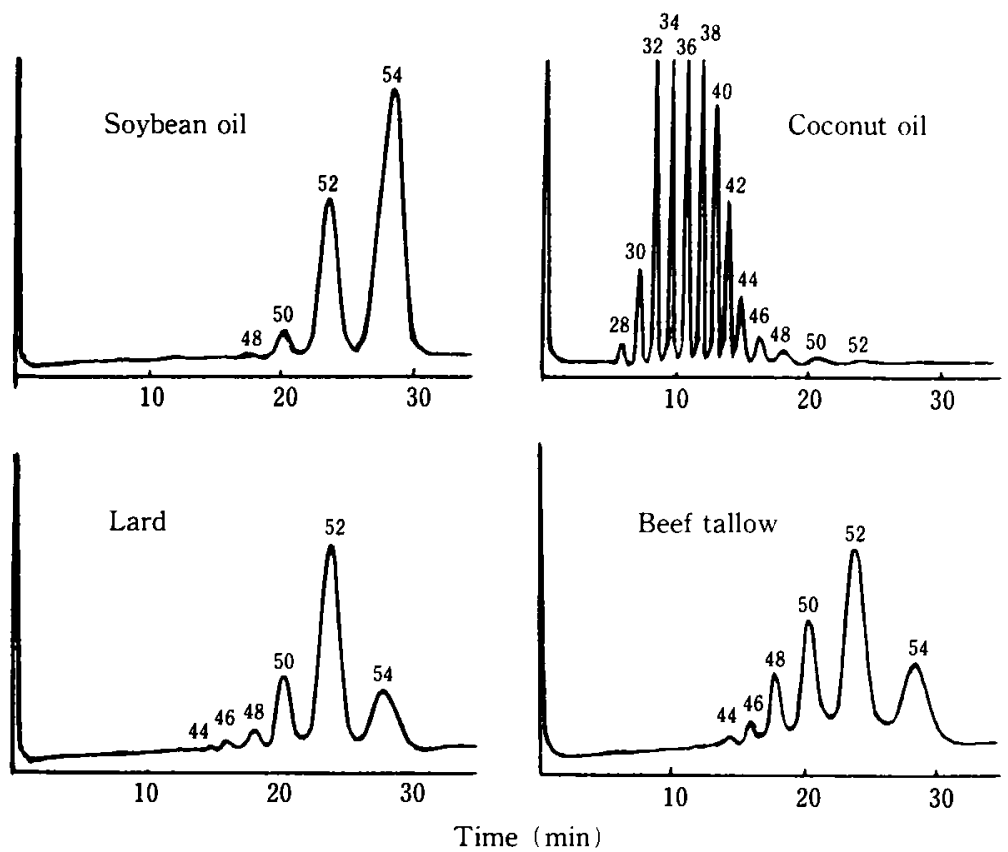

Fig. 1 GLC separation of triacylglycerols of dietary fats

Figures of peaks represent the total number of acvl carbon atoms. Instrument and operating conditions are given in the text.
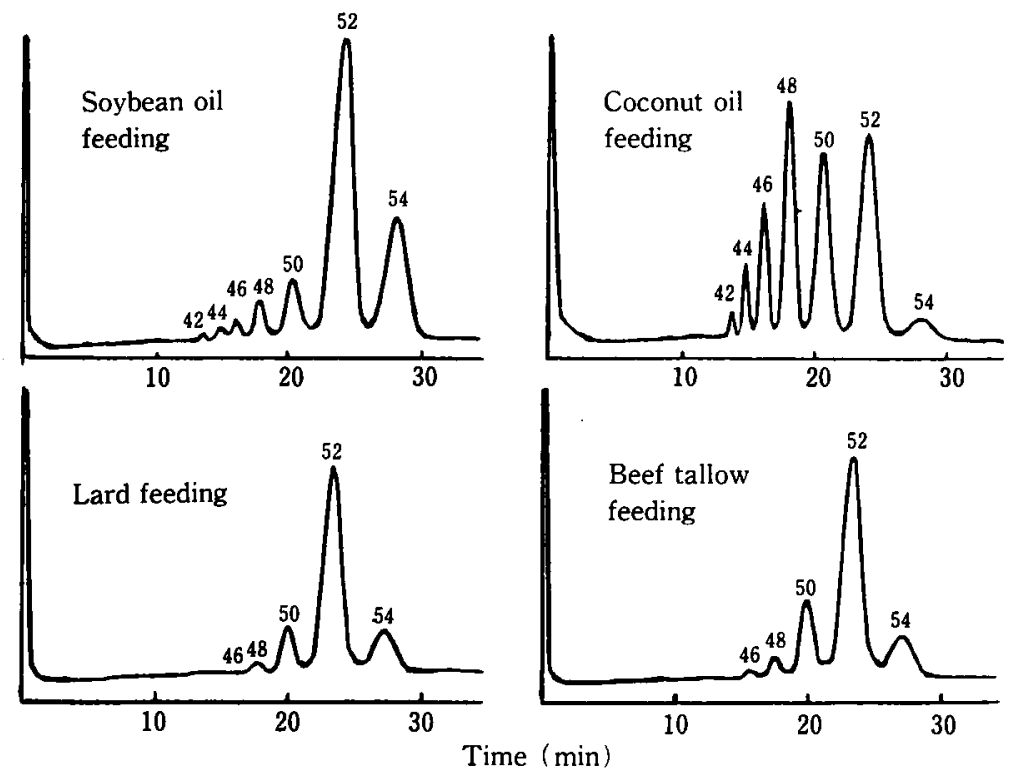

Fig. 2 GLC separation of triacylglycerols of egg yolk lipids from hen fed fat-supplemented diets

Figures of peaks represent the total number of acyl carbon atoms. 
Table 2 Distribution of triacylglycerol types by carbon number in dietary fats and egg yolk lipids from hens fed fat-supplemented diets

(wt. \%)

\begin{tabular}{|c|c|c|c|c|c|c|c|c|}
\hline \multirow{3}{*}{ TG type* } & \multicolumn{4}{|c|}{ Dietary fat } & \multicolumn{4}{|c|}{ Egg yolk TG } \\
\hline & & & & & & tary $f$ & eatme & \\
\hline & SO & $\mathrm{CO}$ & $\mathrm{L}$ & B & SO & $\mathrm{CO}$ & $\mathrm{L}$ & $\bar{B}$ \\
\hline 28 & & 0.8 & & & & & & \\
\hline 30 & & 3.5 & & & & & & \\
\hline 32 & & 13.5 & & & & & & \\
\hline 34 & & 17.3 & & & & & & \\
\hline 36 & & 19.8 & & & & & & \\
\hline 38 & & 17.3 & & & & & & \\
\hline 40 & & 10.7 & & & & & & \\
\hline 42 & & 7.5 & & & 0.5 & 1.5 & & \\
\hline 44 & & 4.1 & 1.0 & 0.4 & 1.0 & 4.2 & & \\
\hline 46 & & 2.1 & 1.9 & 1.6 & 1.9 & 9.5 & & 0.5 \\
\hline 48 & 0.6 & 1.6 & 4.8 & 7.0 & 4.4 & 21.7 & 1.7 & 3.7 \\
\hline 50 & 3.9 & 0.9 & 16.6 & 19.8 & 9.0 & 24.2 & 12.2 & 17.5 \\
\hline 52 & 28.8 & 0.7 & 55.5 & 48.0 & 56.4 & 33.9 & 67.8 & 63.4 \\
\hline 54 & 66.7 & 0.2 & 20.2 & 23.2 & 26.8 & 5.0 & 18.3 & 14.9 \\
\hline
\end{tabular}

* Total number of acyl carbon atoms

Other abbreviations used are the sams as those described in Table 1.

peaks of $T G$ species of $\mathrm{C}_{44} \sim \mathrm{C}_{48}$, resulting from the incorporation of $\mathrm{C}_{12: 0}$ and $\mathrm{C}_{14: 0}$ present in coconut oil into egg yolk lipid.

Distributions of TG types by carbon number in dietary fats and egg yolk lipid were presented in Table 2. Egg yolk of coconut oil group contained considerably more $\mathrm{TG}$ species of $\mathrm{C}_{44}$ $\sim \mathrm{C}_{50}$ and less $\mathrm{C}_{52}$ and $\mathrm{C}_{54}$ than egg yolk TG of the other diet groups. The above-mentioned results were probably caused by scarce incorporation of $\mathrm{C}_{8: 0}$ and $\mathrm{C}_{10: 0}$ present in dietary fat into egg yolk lipid, and by utilization of a small amount of $\mathrm{C}_{12: 0}$ and of fairly amount of $\mathrm{C}_{14: 0}$ for egg yolk lipid formation by laying hens.

Distributions of TG types in egg yolk from lard and tallow groups comparatively resembled mutually, although the lard group contained less $\mathrm{C}_{50}$ and a little more of $\mathrm{C}_{52}$ and $\mathrm{C}_{54}$ than the tallow group, resulting from the less $\mathrm{C}_{16}$ acid and more $\mathrm{C}_{18}$ acid in lard than beef tallow.

Effects of dietary fats on the TGcomposition of egg yolk

TG species of dietary fats and yolk lipids were separated by means of $\mathrm{AgNO}_{3}-\mathrm{TLC}$ depending on the polarity of the TG into diffe-

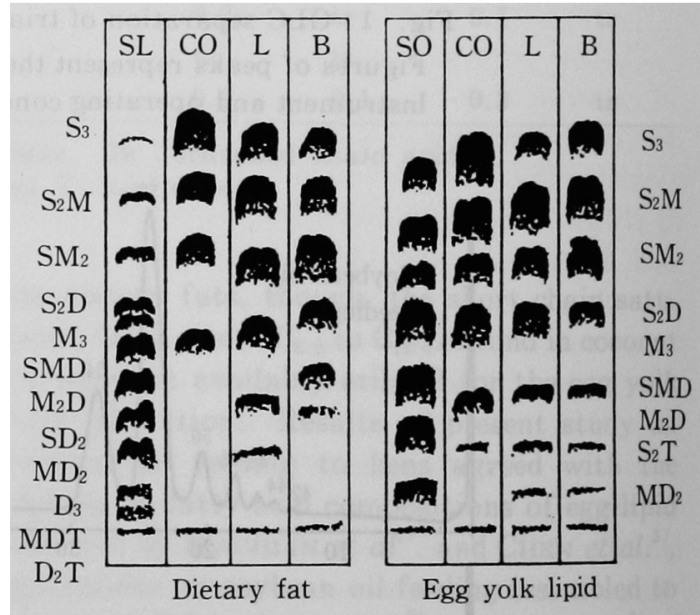

Fig. 3 Argentation thin-layer chromatograms of dietary fats and egg yolk lipids from hens fed fat-supplemented diets

Plate : Silica Gel G implegnated with $10 \%$ $\mathrm{AgNO}_{3}$. Developing solvent system: hexane/ethylether/benzene/methanol (70/10/ 20/1). SO, CO, L and B are soybean oil, coconut oil, lard and beef tallow, respectively (left hand), and respective those fats fed groups (right hand). $\mathrm{S}$ : saturated, $\mathrm{M}$ : monoenoic, $\mathrm{D}:$ dienoic and $\mathrm{T}:$ trienoic fatty acid moieties. 
Table 3 Component triacylglycerol species of dietary fats and egg yolk lipids from hens fed fat-supplemented diets (mole $\%$ )

\begin{tabular}{|c|c|c|c|c|c|c|c|c|}
\hline \multirow{3}{*}{ TG species* } & \multirow{2}{*}{\multicolumn{4}{|c|}{ Dietary fat }} & \multicolumn{4}{|c|}{ Egg yolk lipid } \\
\hline & & & & & \multicolumn{4}{|c|}{ Dietary fat treatment } \\
\hline & SO & $\mathrm{CO}$ & $\mathrm{L}$ & $\mathrm{B}$ & SO & $\mathrm{CO}$ & $\mathbf{L}$ & $\mathrm{B}$ \\
\hline $\mathbf{S}_{3}$ & $\operatorname{tr}^{* *}$ & 56.8 & 4.9 & 11.0 & 1.0 & 5.6 & 1.0 & 1.9 \\
\hline $\mathrm{S}_{2} \mathrm{M}$ & 2.0 & 27.7 & 23.5 & 31.7 & 6.3 & 26.6 & 9.7 & 16.3 \\
\hline $\mathrm{SM}_{2}$ & 2.7 & 6.9 & 28.4 & 34.1 & 16.0 & 39.4 & 40.4 & 47.9 \\
\hline $\mathrm{S}_{2} \mathrm{D}$ & 3.8 & 6.5 & 6.9 & 6.5 & 6.1 & 6.8 & 8.3 & 4.4 \\
\hline $\mathrm{M}_{3}$ & 2.7 & 0.6 & 12.8 & 13.0 & 3.4 & 6.6 & 19.9 & 14.9 \\
\hline SMD & 10.0 & 1.5 & 16.6 & 2.9 & 33.8 & 10.6 & 13.2 & 10.5 \\
\hline $\mathrm{M}_{2} \mathrm{D}$ & 7.0 & & 3.3 & & 10.6 & 2.6 & 5.9 & 3.2 \\
\hline $\mathrm{SD}_{2}$ & 13.1 & & 2.2 & & 5.0 & 0.2 & 0.4 & \\
\hline $\mathrm{S}_{2} \mathrm{~T}$ & 1.9 & & 1.5 & 0.7 & 0.3 & 0.8 & 1.0 & 0.7 \\
\hline $\mathrm{MD}_{2}$ & 17.1 & & & & 5.6 & 0.6 & 0.2 & 0.2 \\
\hline SMT & & & & & 6.8 & & & \\
\hline $\mathrm{M}_{2} \mathrm{~T}$ & & & & & 1.0 & & & \\
\hline $\mathrm{D}_{3}$ & 17.0 & & & & 4.1 & & & \\
\hline SDT & 6.3 & & & & & & & \\
\hline MDT & 10.3 & & & & & & & \\
\hline $\mathrm{D}_{2} \mathrm{~T}$ & 5.9 & & & & & & & \\
\hline
\end{tabular}

* $\mathrm{S}:$ saturated, $\mathrm{M}:$ monoenoic, $\mathrm{D}:$ dienoic and $\mathrm{T}:$ trienoic fatty acid

** tr: trace (below $0.1 \%$ ). Other abbreviations used are the same as those described in Table 1.

rent classes of unsaturation. The results were shown in Fig. 3. Although, more number of bands of TG species were detected on chromatogram in soybean oil and in egg yolk lipid of soybean oil group than in the other TG samples tested, usually several groups of molecular species TG were detected. But for instance, the mixture of $T G$ species of $S_{2} D$ and $M_{3}$, and sometimes, the mixture of $M_{3}$ and SMD were identified as a single band on the chromatogram $^{21)}$ and a similar case was observed among the other TG species (in this, S: saturated, $\mathrm{M}$ : monoenoic and $\mathrm{D}$ : dienoic fatty acid). In such case, the composition of those bands containing mixture of TG species were calculated on the basis of their fatty acid compositions ${ }^{22)}$.

The results of quantitative analysis on $\mathrm{TG}$ components o lietary fats and egg yolk lipids were shown ir. 'able 3. The major TG species in both lard ar beef tallow were $\mathrm{S}_{2} \mathrm{M}$ and $\mathrm{SM}_{2}$, and lard contai $d$ less amounts of trisaturated TG $\left(\mathrm{S}_{3}\right)$ and disaturated monounsaturated TG $\left(\mathrm{S}_{2} \mathrm{U}\right)$ and more of monosaturated diunsaturated
TG $\left(\mathrm{SU}_{2}\right)$ and triunsaturated $\mathrm{TG}\left(\mathrm{U}_{3}\right)$ than beef tallow.

Egg yolk of soybean oil group contained less amounts of TG comprising monoenoic acids $\left(\mathrm{S}_{2} \mathrm{M}, \mathrm{SM}_{2}\right.$ and $\left.\mathrm{M}_{3}\right)$ and more of TG comprising dienoic acid (SMD, $\mathrm{M}_{2} \mathrm{D}, \mathrm{SD}_{2}, \mathrm{MD}_{2}$ and $\mathrm{D}_{3}$ ) than those of the other diet groups. While egg yolk of coconut oil group contained the most amount of $\mathrm{S}_{2} \mathrm{M}$ and the least of $\mathrm{U}_{3}$ among the dietary groups studied. Although the yolk lipid of lard group had more contents of $\mathrm{S}_{2} \mathrm{D}$, $M_{3}$ and SMD species and less of $S_{2} M$ and $S_{2}$ species than that of tallow group, it was considered that lipids from lard and tallow groups were not so far differed in their distribution patterns of TG species.

Effects of dietary fats on the fatty acids distribution in TG of egg yolk

The TG of dietary fats and egg yolk lipids were subjected to stereospecific analyses to investigate the distribution of fatty acids in position 1,2 and 3 of TG. The results obtained were given in Table 4. Position 1 of soybean oil was composed of nearly same amounts of 
Table 4 Positional distribution of fatty acids in triacylglycerols of dietary fats and egg yolk lipids from hens fed fat-supplemented diets

(mole 96)

\begin{tabular}{|c|c|c|c|c|c|c|c|c|c|c|c|c|}
\hline \multirow{3}{*}{ Position } & \multicolumn{12}{|c|}{ Dietary fat } \\
\hline & \multicolumn{3}{|c|}{$\mathrm{CO}$} & \multicolumn{3}{|c|}{$\mathrm{CO}$} & \multicolumn{3}{|c|}{$\mathrm{L}$} & \multicolumn{3}{|c|}{ B } \\
\hline & $1^{*}$ & $2^{*}$ & $3^{*}$ & 1 & 2 & 3 & 1 & 2 & 3 & 1 & 2 & 3 \\
\hline \multicolumn{13}{|c|}{ (Fatty acid) } \\
\hline $8: 0$ & & & & 8.3 & 0.7 & 21.9 & & & & & & \\
\hline $10: 0$ & & & & 6.5 & 3.4 & 10.3 & & & & & & \\
\hline $12: 0$ & & & & 35.1 & 80.8 & 31.4 & & & & & & \\
\hline $14: 0$ & & & & 20.4 & 8.0 & 23.8 & 2.1 & 3.7 & & 2.1 & 6.6 & 2.4 \\
\hline 16 & 24.8 & 6.9 & 2.8 & 12.3 & 1.5 & 9.3 & 26.6 & 51.0 & 0.1 & 32.3 & 19.8 & 25.0 \\
\hline $16: 1$ & & & & & & & 2.5 & 6.0 & 2.3 & 2.9 & 5.5 & 0.9 \\
\hline $18: 0$ & 9.7 & 1.4 & & 3.6 & 0.6 & 2.1 & 18.0 & 4.9 & 13.4 & 25.8 & 7.5 & 20.7 \\
\hline $18: 1$ & 31.2 & 19.0 & 16.4 & 12.6 & 3.7 & 0.6 & 41.4 & 25.0 & 63.8 & 32.1 & 51.0 & 39.0 \\
\hline $18: 2$ & 32.2 & 64.8 & 63.8 & 1.3 & 1.3 & 0.7 & 7.8 & 7.3 & 16.4 & 2.4 & 5.6 & 2.8 \\
\hline $18: 3$ & 1.4 & 7.5 & 16.6 & & & & 0.3 & 0.1 & 1.7 & & 0.4 & 1.1 \\
\hline $20: 1$ & 0.3 & 0.2 & & & & & 0.6 & 0.4 & 2.0 & 0.3 & 0.4 & 1.1 \\
\hline Others** & 0.4 & 0.2 & 0.4 & & & & 0.7 & 1.6 & 0.3 & 2.1 & 3.2 & 6.9 \\
\hline Sat. acid & 34.7 & 8.5 & 2.8 & 86.2 & 95.0 & 98.8 & 47.2 & 60.7 & 13.0 & 62.0 & 35.2 & 52.4 \\
\hline \multirow[t]{2}{*}{ Unsat. acid } & 65.3 & 91.5 & 97.1 & 13.8 & 5.0 & 1.3 & 52.8 & 39.3 & 87.0 & 38.0 & 64.8 & 47.5 \\
\hline & \multicolumn{12}{|c|}{ Egg yolk lipid (Dietary fat treatment) } \\
\hline \multirow[t]{2}{*}{ Position } & \multicolumn{6}{|c|}{$\mathrm{CO}$} & \multicolumn{3}{|c|}{ L } & \multicolumn{3}{|c|}{ B } \\
\hline & $1^{*}$ & $2^{*}$ & $3^{*}$ & 1 & 2 & 3 & 1 & 2 & 3 & 1 & 2 & 3 \\
\hline \multicolumn{13}{|c|}{ (Fatty acid) } \\
\hline $12: 0$ & 0.7 & 0.1 & 0.1 & 0.7 & 2.0 & 3.9 & & 0.3 & & 0.3 & 0.7 & 0.2 \\
\hline $14: 0$ & 1.1 & 1.8 & 2.5 & 5.8 & 5.9 & 18.3 & 0.7 & 0.9 & 0.5 & 0.5 & 2.0 & 1.1 \\
\hline $14: 1$ & & & & u. 2 & 2.9 & 7.4 & & 0.1 & & & 0.2 & 0.4 \\
\hline $16: 0$ & 52.5 & 9.2 & 4.6 & 63.2 & 9.4 & 10.1 & 56.0 & 5.2 & 14.4 & 52.1 & 9.1 & 20.1 \\
\hline $16: 1$ & 0.7 & 2.0 & 5.1 & 5.1 & 6.6 & 11.4 & 5.0 & 2.8 & 6.3 & 0.5 & 4.1 & 10.1 \\
\hline $18: 0$ & 7.4 & 3.9 & & 3.9 & 3.7 & 3.5 & 4.9 & 2.7 & 3.8 & 12.5 & 4.2 & \\
\hline $18: 1$ & 24.0 & 26.3 & 61.9 & 17.7 & 52.1 & 43.6 & 28.6 & 64.6 & 72.7 & 29.9 & 63.9 & 66.8 \\
\hline $18: 2$ & 12.0 & 53.9 & 20.3 & 2.3 & 16.2 & 0.7 & 3.9 & 22.6 & 0.5 & 3.2 & 13.3 & 0.3 \\
\hline $18: 3$ & 0.8 & 2.3 & 3.2 & & 0.6 & 0.6 & 0.2 & 0.4 & & 0.2 & 0.9 & \\
\hline $20: 1$ & 0.3 & 0.2 & 0.1 & 0.1 & 0.3 & 0.5 & 0.1 & 0.1 & 0.7 & 0.2 & 0.4 & 0.3 \\
\hline Others** & 0.3 & 0.3 & 2.2 & & 0.3 & & 0.6 & 0.3 & 1.1 & 0.6 & 1.2 & 0.7 \\
\hline Sat. acid & 62.1 & 15.3 & 7.2 & 74.6 & 21.1 & 36.0 & 61.8 & 9.2 & 18.8 & 65.8 & 16.3 & 22.2 \\
\hline Unsat. acid & 37.9 & 84.7 & 92.8 & 25.4 & 78.9 & 64.1 & 38.2 & 90.8 & 81.2 & 34.2 & 83.7 & 77.7 \\
\hline
\end{tabular}

* Stereospecific number in triacylglycerol

** Contained $14: 1,15: 0,17: 0 \mathrm{br}, 17: 0,17: 1$ and $20: 4$

Other abbreviations used are the same as those described in Table 1.

saturated, monoenoic and dienoic fatty acids, both of position 2 and 3 were occupied over 60 $\%$ by dienoic acid, and small amounts of saturated acids were found in position 2 and 3.

In egg yolk TG from soybean oil group, $\mathrm{C}_{16: 0}$ and $\mathrm{C}_{18: 0}$ were preferentially esterified in posi- tion 1, consequently this position was occupied largely by saturated fatty acids. Position 2 comprised predominantly unsaturated fatty acids, mostly $\mathrm{C}_{18: 2}$ in the case of soybean oil group. Position 3 was largely occupied by $\mathrm{C}_{18: 1 \text {. }}$. This characteristic feature of positional 
distribution of fatty acid in egg TG from soybean oil group, i,e. the preferential distributions of unsaturated fatty acids in position 2 and 3 of TG, was similarly observed in egg TG from the other dietary groups, though the position 2 of TG from coconut oil, lard and tallow groups were mainly composed of $\mathrm{C}_{18} \cdot 1$ instead of $\mathrm{C}_{18: 2}$ in the case of the soybean oil group.

The arrangement of fatty acids in TG of egg yolk from each dietary group was fairly different from those of respective dietary fats fed to hens, for example unusual fatty acid distribution of lard was not observed in the egg yolk TG from lard group. Digested dietary fat, absorbed by intestinal epithelium, is again esterified to TG probably accomanying with rearrangement of fatty acids in TG molecule, and thus resynthesized TG enters to hepatic portal blood stream as lipoproteins ${ }^{23)}$. This lipoproteins and TG synthesized de novo in liver are utilized for the formation of egg yolk lipids in ovary, maintaining the species specificity of hen's egg. Consequently, as described by HuSBANDS ${ }^{24)}$, fatty acids of the 1, 3-and 2positions in liver and in egg yolk TG show a similar distribution, in contrast to this, fatty acids arrangement in TG of egg yolk differs from that of dietary fat fed to laying hen.

Effects of dietary fats on the stereospecific structure of egg yolk TG
The amounts of individual species of TG could be calculated from the known fatty acids distribution in intact TG assuming a 1-random, 2-random, 3-random arrangement. Results obtained on TG of dietary fats and of egg yolk from each dietary group were given in Table 5.

The most abundant TG species in soybean oil was sn-UUU, followed by sn-SUU and sum amount of these two types of TG was attained nearly $90 \%$ of total TG of oil (in this, snmeans stereospecifically numbered). In contrast to soybean oil which contained only trace of sn-SSS, the amount of this TG was calculated for over $80 \%$ in coconut oil. Major TG of lard was the saturated fatty acids mostly present in position 2 of TG such as sn-SSU and sn-USU, on the other hand, beef tallow comprised sn-SUS and sn-SUU as main TG species. The most abundant TG species of egg yolk from every diet group was sn-SUU, then followed by sn-UUU except coconut group.

Table 6 compares the amounts of the TG groups determined by $\mathrm{AgNO}_{3}-\mathrm{TLC}$ with those calculated by the 1-random, 2-random, 3random distribution. In general, the agreement is comparatively good, excepting the case of coconut oil TG, in which fairly large differences were recognized between the amounts found by $\mathrm{AgNO}_{3}-\mathrm{TLC}$ procedure and the values calculated by random hypothesis. That discrepancies observed among the values from different

Table 5 Predicted triacylglycerol compositions of dietary fats and egg yolk lipids from hens fed fat-supplemented diets

\begin{tabular}{|c|c|c|c|c|c|c|c|c|}
\hline \multirow{3}{*}{ TG type** } & \multicolumn{4}{|c|}{ Dietary fat } & \multirow{2}{*}{\multicolumn{2}{|c|}{$\frac{\text { Egg }}{\text { Dielar }}$}} & \multirow{2}{*}{\multicolumn{2}{|c|}{$\begin{array}{l}\text { k lipid } \\
\text { treatment }\end{array}$}} \\
\hline & & & & & & & & \\
\hline & SO & $\mathrm{CO}$ & $\mathrm{L}$ & $\mathrm{B}$ & SO & $\mathrm{CO}$ & $\mathrm{L}$ & $\mathrm{B}$ \\
\hline sn-SSS & 0.1 & 81.9 & 3.9 & 11.4 & 0.7 & 5.7 & 1.1 & 2.6 \\
\hline sn-SSU & 2.9 & & 24.7 & 10.4 & 8.8 & 10.1 & 4.6 & 8.2 \\
\hline sn-SUS & 0.9 & 4.3 & 2.5 & 21.1 & 3.7 & 21.2 & 10.6 & 13.1 \\
\hline sn-USS & 0.2 & 13.1 & 4.4 & 7.0 & 0.4 & 1.9 & 0.7 & 1.3 \\
\hline sn-SUU & 30.9 & & 16.0 & 19.1 & 48.8 & 37.6 & 45.7 & 41.9 \\
\hline sn-USU & 5.4 & & 27.7 & 6.4 & 5.4 & 3.4 & 2.8 & 4.3 \\
\hline sn-UUS & 1.7 & 0.7 & 2.8 & 12.9 & 2.3 & 7.2 & 6.5 & 6.8 \\
\hline sn-UUU & 58.1 & & 17.9 & 11.7 & 29.8 & 12.8 & 28.0 & 21.8 \\
\hline
\end{tabular}

*Calculated triacylglycerol type by means of 1-random, 2-random, 3-random distribution.

** $\mathrm{sn}$ - : stereospecifically numbered. $\mathrm{S}$ : saturated, $\mathrm{U}:$ unsaturated fatty acid. Other abbreviations used are the same as those described in Table 1. 
Table 6 Comparison of observed and predicted values of triacylglycerols of dietary fats and egg yolk lipids

(mole \%)

\begin{tabular}{|c|c|c|c|c|c|c|c|c|}
\hline \multirow{3}{*}{ TG type } & \multirow{2}{*}{\multicolumn{4}{|c|}{ Dietary fat }} & \multicolumn{4}{|c|}{ Egg yolk lipid } \\
\hline & & & & & & etary & reatm & \\
\hline & so & $\mathrm{CO}$ & $\mathrm{L}$ & B & So & $\mathrm{CO}$ & $\mathrm{L}$ & B \\
\hline \multirow[b]{2}{*}{$\mathrm{S}_{3}$} & $\operatorname{tr}$ & 56.8 & 4.9 & 11.0 & 1.0 & 5.6 & 1.0 & 1.9 \\
\hline & 0.1 & 81.9 & 3.9 & 11.4 & 0.7 & 5.7 & 1.1 & 2.6 \\
\hline \multirow{2}{*}{$\mathrm{S}_{2} \mathrm{U}\left\{\begin{array}{l}\text { Found } \\
\text { Calculated }\end{array}\right.$} & 7.7 & 34.2 & 31.9 & 38.9 & 12.7 & 34.2 & 19.0 & 21.4 \\
\hline & 4.0 & 17.4 & 31.6 & 38.5 & 12.9 & 33.2 & 15.9 & 22.6 \\
\hline \multirow{2}{*}{$\mathrm{SU}_{2}\left\{\begin{array}{l}\text { Found } \\
\text { Calculated }\end{array}\right.$} & 32.1 & 8.4 & 47.2 & 37.0 & 61.6 & 50.2 & 53.9 & 58.4 \\
\hline & 38.0 & 0.7 & 46.5 & 38.4 & 56.5 & 48.2 & 55.0 & 53.0 \\
\hline \multirow{2}{*}{$\mathrm{U}_{3}\left\{\begin{array}{l}\text { Found } \\
\text { Calculated }\end{array}\right.$} & 60.0 & 0.5 & 16.1 & 13.0 & 24.7 & 9.7 & 26.0 & 18.3 \\
\hline & 58.1 & & 17.9 & $11: 7$ & 29.8 & 12.8 & 28.0 & 21.8 \\
\hline
\end{tabular}

* Obtained from analysis by means of argentation thin-layer chromatography.

** Calculated from data obtained by means of stereospecific analyses.

Other abbreviations used are the same as those described in Table 1.

methods may be due to the reasons that, on the one hand, coconut oil TG assumed non-random distribution of fatty acid and/or that, on the other hand, the partial deacylation with a Grignard reagent was not enough suitable to provide DG from coconut oil containing medium molecular weight TG. Although, ethyl magnesium bromide i. e. Grignard reagent is usually used for the standard procedure of stereospecific analysis, MORRISON and $\mathrm{HAWKE}^{25)}$ recommended that pancreatic lipase gave relatively representative $1,2(2,3)-\mathrm{DG}$ from the low and medium weight TG.

Egg yolk lipids from every dietary group showed fairly good agreements, though not complete, between their actual and predicted values of TG. CHRISTIE and MOORE ${ }^{26)}$ obtained good agreement between actual and predicted values of TG on the hen's egg. From these results, a 1-random, 2-random, 3-random distribution of the fatty acids was assumed on the hen's egg yolk TG.

\section{References}

1) Fischer, H. and Leveille, G.H. : J. Nutr., 63, 119 (1957).

2) Chen. P.H., Common. R.H., Nikolaiczek. N. and MAcRAE, H.F.: J. Food Sci., 30, 838 (1965).

3) Sim, J.S., BragG, D.B. and Hodgson, G.C. : Poultry Sci., 52, 51 (1973).

4) Ostrander, J.G., Jordan, R., Stadelman,
W.J., ROGLER, J.C. and VAIL, G.E. : Poultry Sci., 39, 796 (1960).

5) Evans, J.F., Bandmer, J.A. and Davidson, J.A. : J. Nutr., 39, 1199 (1960).

6) Leveille, G.A. and Fischer, H.: Poultry Sci., 37, 658 (1958).

7) Machlin, L.J., Gordon, R.S., Marr, J. and Pope, C.W.: Poultry Sci., 41, 1340 (1962).

8) Sell, J.L., Choo, S.H. and Kondra, P.A.: Poultry Sci., 47, 1296 (1968).

9) Hirata, A., Nishino, M., Kimura. T. and Ohtake, Y.: Nippon Shokuhin Kogyo Gakkaishi, 32, 892 (1985).

10) Couch, J.R. and Saloma. A.E. : Lipids, 8 , 385 (1973).

11) Ohtake, Y. and Hoshino, Y: Jap. J. Zootech, Sci., 47, 430 (1976).

12) Folch, J., Leas, M. and Stanley, G.H.S.: J. Biol. Chem., 226, 497 (1957).

13) MoercK, K.E. and Ball, Jr., H.R.: J. Food Sci., 38, 978 (1973).

14) WoOD, R. and SNyder, F.: J. Am. Oil Chem. Soc., 43, 53 (1966).

15) Christie, W.W. and Moore, J.H. : Biochim. Boiphys. Acta, 210, 45 (1970).

16) Ohtake, Y.: Jap. J. Zootech. Sci., 54, 179 (1983).

17) Brockerhoff, H.: J. Lipid. Res., 6, 10 (1965).

18) Christie, W.W. and Moore, J.H.: Biochim. Biophys. Acta, 176, 445 (1969).

19) Kuksis. A., McCarthy, M.J. and Beverigr, J.M.R.: J.Am. Oil Chem. Soc., 40, 530 
(1963).

20) OHTAKe, Y.: Jap. J. Zootech. Sci., 53, 797 (1982).

21) Christie, W.W. and Moore, J.H. : Lipids, 4, 345 (1969).

22) Blank, M.L., Verdino, B. and Privett, O.S. : J. Am. Oil Chem. Soc., 42, 87 (1965).

23) Noyan, A., Lossow, W.J., Brot, N. and Chiakoff, I.L. : J, Lipid Res., 5, 583 (1964).

24) Husbands, D.R. : Biochem. J., 120, 365 (1970).

25) Morrison, I.M. and Howke, J.C. : Lipids, 12, 1005 (1977).

26) Christie, W.W. and Moore, J.H. : Biochim. Biophys. Acta, 218, 83 (1970).

(Received Oct. 6, 1986)

卵黄のトリアシルグリセロール組成ならひに

構造におよほす飼料油脂の影響

平田明弘* ・增田哲也*

木村貞司* ・ 大武由之*

*日本大学農獣医学部（干154 東京都世田谷区

下馬 3-34-1)

大豆油, ココヤシ油, ラードならびに牛脂の給与が,
鶏卵卵黄のトリアシルグリセロール（TG）の組成およ び構造に及ぼす影響を調べた。短鎖飽和脂肪酸は卵黄脂 質の生成に利用されなかったか，卵黄 TGは一般に飼 料油脂の脂肪酸組成を反映するところがあった，大豆油 区，ラード区おょび牛脂区の卵黄 TG はいずれも $\mathrm{C}_{50}$ ， $\mathrm{C}_{52}$ および $\mathrm{C}_{54}$ の TGを主な構成成分としていた。 コヤシ油区の卵黄には，かなりの量の $\mathrm{C}_{44}$ から $\mathrm{C}_{50}$ ま での TG 㮔が含まれ，反面 $\mathrm{C}_{52}<\mathrm{C}_{54}$ の成分は試験区 中で最も少なかった，大豆油区の即黄脂質は他の飼料区 のものに比べて，(モノエン酸を含む TG の量が少なく， ジェン酸を含む TG が多かった。ココヤシ油区の卵黄 脂質は，他の飼料区に比べて $\mathrm{S}_{2} \mathrm{M}$ が最む多く $\mathrm{U}_{3}$ 成分 が最も少なかった．ラード区と牛脂区との TG 種の分 布パターンは類似していた。いずれの飼料区の卵黄脂質 にあっても，飽和脂肪酸は TGの1-位置に優先的にエ ステル化し，これに対して 2-位置は顕著に不飽和脂肪 酸で占められ，3-位置には $\mathrm{C}_{16: 1}$ とともに $\mathrm{C}_{18: 1}$ が多か った。このような鵎卵卵黄の TG内における脂肪酸の 位置的分布の種属的特異性は, 飼料中の油脂の違いにか かわらず变化が認められなかった（ $\left(\mathrm{C}_{50}\right.$ はアシル炭素 原子数 50 の TGで，他はこれに準ずる．また，Sは飽 和脂肪酸， M はモ/エン酸，Uは不飽和脂肪酸をあら わす.) 